\title{
GESCHIEDENIS DER CACAOCULTUUR IN SURINAME
}

DOOR

\author{
A. REYNE
}

(Vervolg)

\section{CULTUUR, OOGST EN BEREIDING}

3. Er werden geen schaduwboomen geplant. Gebruik van windbrekers

In bijna alle cacao-verbouwende landen wordt de cacao gekweekt onder schaduwboomen; zoo bijv. in Suriname onder koffiemama (Erythrina glauca Willd); in enkelelanden, bijv. Grenada en Brazilië, kweekt men de cacao ook zonder blijvende schaduw; echter gebruikt men in de eerste jaren daar wel hulpschaduw (bananen enz.) voor de jonge cacaoplanten; gedeeltelijk geschiedt dit ook met het doel om iets van den grond te halen, zoolang de cacao-aanplanting nog niet produceert.

De cultuurwijze van Grenada zonder schaduw, die van vrij recenten datum is ${ }^{1}$ ), verschilt zeer van die op Trinidad met schaduw. Omstreeks 1900 en later is er over het schaduwvraagstuk in Britsch West-Indië veel gestreden $\left.{ }^{2}\right)$. Als voordeel van de cultuurwijze van Grenada wordt aangenomen, dat de cacaoboomen eerder produceeren en meer vruchten geven. Vele planters op Trinidad zijn echter van oordeel dat op hun eiland het niet voordeelig of zelfs on-

1) Van omstreeks 1895 (W. I. bull. VI, p. 75).

$\left.{ }^{2}\right)$ Zie P. Preuss-Expedition nach Central- und Süd-Amerika 1901, p. 186. W. I. bull. VI (1906), p. 74-78. Agric. News IV (1905) p. 162, XVI (1917), p. 33. J. H. Hart, Cacao (1900), p. 11, (1911), p. 44/9.v. Proc. Agr. Soc. of Trinidad, verschillende plaatsen. 
mogelijk zou zijn om cacao zonder schaduw te planten.

Met deze discussiën rees de vraag: welke beteekenis hebben de schaduwboomen bij de cacaocultuur?

Een uitvoerige beschouwing over dit onderwerp gaf Dr. C. J. J. van Hall in bull. 7 van de Inspectie van den Landbouw in West-Indië (Paramaribo 1906). Van Hall ${ }^{1}$ ) komt tot de volgende conclusies:

1. De cacaoboom kan zeer goed het volle zonlicht verdragen en is hiervoor zelfs dankbaar, zooals blijkt uit grootere productiviteit.

2. Het nut van den schaduwboom is gelegen in de grondverbetering, die hij tot stand brengt door het koel houden van den bodem en het tegengaan van de vertering van den humus, voorts in het aanbrengen van humus door bladafval, in het losmaken van den bodem door zijn wortelgestel en in het verrijken van den bodem met stikstof. Ook als windbreker bewijst de schaduwboom dienst.

3 . Wil men de cacao zonder schaduw kweeken, dan zullen in het algemeen de opgenoemde nuttige uitwerkingen op andere wijze bereikt moeten worden; dit kan geschieden zooals op Grenada door zware bemesting en dergelijke grondbewerking of door tusschenplanting van een laagblijvend gewas, zooals dat in onze proefvelden plaats vindt ${ }^{2}$ ).

4. Op deze wijze zal de cacaocultuur zonder schaduwboomen altijd een veel intensievere cultuur zijn, die hoogere kosten met zich meebrengt maar ook hoogere opbrengsten geeft.

5. Of zulk een intensievere cacaocultuur practisch uitvoerbaar is, hangt van locale omstandigheden af."

Hart $^{3}$ ) meende, dat in het geaccidenteerde terrein op Grenada de bergen zelf als schaduwgevers optraden; Preuss ontkent dit en meent dat de grootere vochtigheid van de lucht en de sterkere bewolking op Grenada de schaduwboomen overbodig maken in tegenstelling met Trinidad.

1) Vergl. ook C. J. J. van Hall. Cocoa, London 1914, p. 148-152.

$\left.{ }^{2}\right)$ Daarvoor werd Cajanus indicus (wandoe, pigeonpea) gebruikt.

3) J. H. Hart. Cacao, London 1911 (Port of Spain 1900). 
J. B. Harrison (Br. Guiana) is van oordeel dat de schaduwboomen alleen noodig zijn voor windbrekers en dat de schaduw ter wille van de productie tot een minimum gereduceerd moet worden (Timehri, 1918, p. LVIII e. v.).

Van Hall daarentegen is van meening, dat het voorvoornaamste nut van de schaduwboomen gelegen is in den gunstigen invloed, die ze op den bodem uitoefenen. Dat deze opvatting voor de tegenwoordige Surinaamsche plantages juist is, hebben de ervaringen, die men later heeft opgedaan met koffieaanplantingen onder Hevea-schaduw, zeer waarschijnlijk gemaakt. Liberia-koffie groeit onder Hevea-schaduw zeer slecht, terwijl de schaduw, die de Hevea aan de koffie geeft, slechts weinig verschilt met die der koffiemama (Erythrina glauca), waar onder de Liberia-koffie zeer goed groeit. Treffend was in vele gevallen de verandering ten goede, die in de koffievelden optrad, toen de Hevea's door koffiemama's vervangen werden.

In verband met het bovenstaande, kan als een der voornaamste resultaten dezer historische studie zekèr gelden, dat de cacao in Suriname 1 $\frac{1}{2}$ eeuw lang zonder schaduwboomen gekweekt is (evenals de koffie).

Teenstra (1834) vermeldt in zijn beschrijving van de cacaocultuur in Suriname, dat men in Caracas de cacaoboomen plant onder de schaduw van reeds vroeger geplante boomen. „De jonge kakauplant (wordt) eerstelijk overschaduwd door bananenboomen, en grooter geworden, roeit men de bananen uit, en laat den om de andere rij geplanten koraalboom (erythrine) tusschen de kakau staan. De Spanjaarden planten twee soorten van erythrine-boomen, op Java dadap ${ }^{1}$ ) geheeten.... Men kent dezelve in Suriname beter onder den naam van koffy mama of zandkokers, wordende hier een zware boom.'

Hieruit moet men opmaken, dat het planten van koffiemama tusschen de cacao in Suriname niet plaats vond. Ook in Teenstra's beschrijving van de koffiecultuur wordt ner-

1) Erythrina lithosperma Bl. en andere. 


\title{
110 GESCHIEDENIS DER CACAOCULTUUR IN SURINAME
}

\author{
gens gewag gemaakt van het planten dezer boomen in de \\ koffiestukken.
}

Wel teekent hij aan, dat de bananenplant dient om de koffie tegen zon en wind te beschutten, zoodat ze in Suriname de plaats vervangt van de op Java tusschen de koffie groeiende „dadap”. Teenstra, die tevoren.eenige jaren op Java in den landbouw werkzaam was, kende waarschijnlijk den „dadap" (Erythrina sp.) uit eigen aanschouwing. Hij houdt den „dadap” voor een beter schaduwboom, omdat deze zijn bladeren op den juisten tijd afwerpt.

Bij zijn beschrijving der houtsoorten teekent Teenstra over den postentrie (Hura crepitans L.) aan, ,Sommigen beweren, dat deze Postentrie een soort van Erythrine is, welke de Spanjaarden van Caracas Bucare anaveo $\left.{ }^{1}\right)$ heeten.

Anderen verwarren de Koffymama of den Orenokkeboom ${ }^{2}$ ) met den Postentrie; echter heeft de eerste meer overeenkomst met den Dadap der Javanen."

De beschrijving, die T. echter van „den Surinaamsche Postentrie” geeft, bewijst, dat het werkelijk een Erythrina, waarschijnlijk de tegenwoordige koffiemama is, welke hij op het oog heeft. De bladeren vallen aan het einde van den drogen tijd af; de bladerlooze boom draagt dan roode bloemen. Het onderste gedeelte van de bloem bestaat uit een oranjekleurige „bladsleuf", daarop volgen twee bleekgele blaadjes met purperkleurige punten, waarboven twee andere „sleufvormige blaadjes" staan, waaruit 10-12 meeldraden komen.

De beschrijving, die dan volgt van de vrucht (8-hoekig geribd zaad, bekend als ,zandkoker" 3 ) en van het zeer giftige melksap en de geschiktheid voor „vlieringplanken" slaat echter wel op den postentrie (Hura crepitans L.).

Nog tegenwoordig wordt in het district Nickerie de koffiemana, Erythrina glauca Willd, aangeduid als ",sandbox", hoewel die naam aan H. crepitans toekomt (vanwege het gebruik der vruchten).

Ook in Noord-Brazilië hebben Hura crepitans L. (assacú) en Erythrina glauca Willd (assacú rana of assacú) denzelfden naam ${ }^{4}$ ).

Inderdaad vertoonen de beide boomen uiterlijk eenige overeenkomst, wat den stekeligen stam betreft, zoodat bij oppervlakkige beschouwing verwarring mogelijk is. De koffiemama bevat echter geen melksap, de postentrie heeft geen roode bloemen en staat in den drogen tijd niet kaal.

Volgens Teenstra vond men in Matappica een groote hoeveelheid „postentrie" vóor de koffiestukken, tot bescherming tegen de „schrale zeewinden". Wanneer men aanneemt, dat dit koffiemama geweest is en dat men

1) $=$ Bucare anauco = Erythrina umbrosa, ook tegenwoordig nog in Venezuela en Trinidad als schaduwboom voor cacao gebruikt. (Vergl. R. de Grosourdy, El Medico botànico 1864, dl. II, p. 452).

$\left.{ }^{2}\right)$ In Br. Guiana, waar Erythrina glauca Willd gebruikt wordt als in Suriname, heet deze nog thans "Oronoque tree”.

3) Met den naam zandkoker wordt bij Nepveu, Hartsinck en Blom, Hura crepitans L. bedoeld (vergl. Eng. ,sandbox”, Fr. „sablier”.).

4) J. Huber. Arboretum Amazonicum 1900, pl. 14. Boletim do Museu Goeldi dl. VI (1909) p. 183. 


\section{GESCHIEDENIS DER CACAOCULTUUR IN SURINAME 111}

deze oorspronkelijk als windbrekers gebruikte voor de koffieplantages is de oorsprong van den naam „koffiemama” ook verklaard.

Voor zoover mij bekend is, komt die naam in de uitvoerige Surinaamsche litteratuur vobr Teenstra nergens voor.

Wel vindt men bij Aublet (1775) den naam „mamam cacao"; zoo noemden de inwoners van Cayenne Hura Crepitans L. (de vrucht echter „sablier"). Misschien diende die boom in Cayenne tot windbreker voor de cacao. Volgens H. Jumelle (Le cacaoyer, Paris 1900) wordt hij nog wel als zoodanig gebruikt. Op Trinidad dient Hura soms als schaduw voor cacao. Erythrina heet bij Barrère (1734) en Aublet „immortel”, welke naam thans nog in gebruik is.

De veronderstelling, dat de koffiemama eerst tegen het midden der 19de eeuw bij de koffiecultuur is ingevoerd en wel oorspronkelijk als windbreker, laat zich nader bevestigen.

H. C. Focke, die met de flora van Suriname goed bekend was, schrijft in $\left.1855^{1}\right)$ in zijn Neger-Engelsch woordenboek bij het woord „koffiemama”: „een hooge boom van dien naam, die, vooral aan den zeekant, in de koffiestukken geplant wordt, om den koffy-heester tegen zware winden te beschermen (Erythrina glauca G. F. W. Meyer).

H. W. Lans (1829) zegt, dat in Matappica-, Warappa-, en Motkreek vroeger de beste koffielanden waren, maar dat de oogsten er sterk achteruit gegaan zijn, volgens het gevoelen der beste planters, omdat na de ontwikkeling der katoenteelt aan de monding der kreeken de bosschen aan zee, „die de koffielanden als een gordijn beschermden tegen de zeewinden' zijn opgeruimd. Waar het bosch gebleven is, als in de Commewijne en Cottica, zijn de oogsten nog goed.

De groote hoeveelheid „postentrie” (blijkbaar koffiemama), die volgens Teenstra later aanwezig was tot bescherming tegen de schrale zeewinden vobr de koffiestukken in Matappica, is wellicht geplant om dit euvel te verhelpen.

Wat de aanleiding is geweest om dezen windbreker later in de koffiestukken te gaan planten, zooals Focke (1855) meedeelt, is niet bekend.

In de voormalige koffievelden (Surinaamsche koffie) der plantages aan de Commewijne en Suriname schijnt men zelfs nooit koffiemama geplant te hebben. In een inventaris der koffieplantage Jagtlust van 1850 vindt men bij de beschrijving der koffiestukken steeds de uitdrukking: „.... koffieboomen met de bananen geplant in het verband", ook voor velden waar de koffie reeds 30 jaar en ouder was. Hieruit en uit andere gegevens blijkt, dat op deze plantage de Surinaamsche koffie niet alleen in de jonge maar ook in de oude velden een tusschenplanting van bananen had. Eerst omstreeks 1870 toen deze plantage in een cacaoplantage werd omgezet, werden alle velden met koffiemama beplant (de stekken daarvoor werden uit de kapoewerie gehaald. Met welk doel was daar vroeger koffiemama geplant?).

1) Bij C. A. van Sypesteyn: Over Surinaamsche houtsoorten, West-Indië, dl. I, blz. 176 (1856): Koffy-mama, Erythrina corallodendron L., E. glauca Wil. Zelden wordt dit hout gebruikt, dat ook slechts in kleine afmetingen voorkomt. De boom veelal aangeplant tot bescherming der jonge koffieboomen.

In H. C. Focke, Lijst der planten, welke in de kolonie Suriname gekweekt worden. (Tijdschrift voor de Wis- en Natuurkundige Wetenschappen 1848) wordt de koffiemama, E. glauca, G. F. W. Meyer, ook genoemd. 


\section{GESCHIEDENIS DER CACAOCULTUUR IN SURINAME}

Een bejaard inwoner van Paramaribo deelde mij mee, dat hij zich de koffieplantage Killenstein uit het jaar 1862 herinnerde. Ook daar vond men in de oude koffievelden geen koffiemama, maar een tusschenplanting van bananen.

$\mathrm{Nu}$ is het ook beprijpelijk waarom Teenstra (1835) zegt, dat in Suriname de banaan de plaats vervangt van de op Java tusschen de koffie groeiende "dadap".

Als bewijs dat vóor Teenstra de koffie in Suriname steeds zonder schaduwboomen geplant is, moge nog gelden dat door geen der oudere schrijvers die uitvoerig over de koffiecultuur spreken (Handschrift 1740, Nepveu 1770, Blom ${ }^{1}$ ) 1787, Guizan 1788, Verhandelingen 1804) over het planten van schaduwboomen gerept wordt. F. W. Hostmann, die sedert 1818 in Suriname was, schrijft in een in 1850 gepubliceerd boek (Over de beschaving van negers in Amerika enz.), dat naar zijn oordeel de koffieboom, ten minste in de vlakten, niet zonder schaduw behoort op te groeien, in Suriname echter „laat men hem in het open veld opgroeijen, veel meer aan de zon bloot staande, dan dit gewas kan verdragen".

In de opstellen over koffiecultuur in het tijdschrift: de Kolonist (Paramaribo 1839) p. $227-232,264-278,291-295$ : wordt nergens over schaduwboomen gesproken, in het laatste opstel wordt zelfs gezegd, dat de koffieboom de volle zon en veel lucht behoeft. Van Raders en Wolfson deelen in hun reisverslag (Paramaribo 1846) mee, dat de koffie op Grenada onder een beschermenden boom geplant wordt. In Suriname geschiedde dat dus blijkbaar niet.

In de Spaansche landen zijn schaduwboomen voor cacao („,madre de cacao”) van ouds in gebruik geweest (vergel. G. Benzoni midden 16de eeuw, D. Ch. de Rochefort midden 17de eeuw, Pertinente beschrijvinghe van Guiana, 1676).

Erythrina werd omstreeks 1800 zeker reeds gebruikt als schaduwboom voor cacao in de Spaansche landen (vergl. B. Edwards, History British Colonies in the West

1) Blom acht het in een latere publicatie (1801) niet ondienstig om op schrale gronden, waar de middagzon en wind voor de koffie nadeelig is, deze licht te beschaduwen door tusschenplanting met „boschpapaijen" (Cecropia peltata) op 40-60 voet afstand.

Op Victoria (bov. Suriname) bijv. waar de grond zeer los en spongieus was, meende Blom, dat het zeer goed zou zijn om de jonge koffie en cacao te beschaduwen ò met boschpapaja's (opgegroeid tot 16 voet lengte 5060 voet plantwijdte) ò met bananen ( $20-50$ voet plantwijdte). De boschpapajas moesten tegelijk met koffie en cacao geplant worden.

In de verhandelingen der plantersvereeniging „De Eensgezindheid” (1804) wordt daarentegen protest aangeteekend tegen de meening, dat de bananen op de koffie nuttig werken door de schaduw die ze geven: „het strijdt tegen de natuur en gezonde reden, dat de eene boom of plant onder de ander niet behoorlijk groeien en zich uitzetten kan, maar onderdrukt wordt, en zulks daarom nooit moet geschieden". 
Indies vol. II. G. A. Porter, Tropical Agriculturist 1833; Guizan 1825, p. 396-402.

Geen der beschrijvingen voor Suriname van vóór $1830^{1}$ ) spreekt echter over het planten van schaduwboomen in cacaostukken. (Verhandelingen plantersvereeniging „de Eensgezindheid" 1804, Blom 1801, Blom 1787, Guizan 1788, Nepveu 1770, handschrift planter 1740-1747). Het zou zeker toevallig zijn als al deze schrijvers, die ervaring hadden van de cacaocultuur in Suriname en ze vrij gedetailleerd beschrijven, juist dit punt vergeten hadden.

Als een duidelijk bewijs dat de cacao zonder blijvende schaduwboomen geplant werd, kan de volgende plaats bij Blom (1786) gelden.

Men heeft hier op de plantage Tourtonne de proef genomen niet alleen met rondom de stukken, maar ook in de stuk$k e n$, langs de kleine trenzen, gemeen waterhout ${ }^{2}$ ) te planten, en men ziet niet alleen dat deszelfs schaduw aan de cacaoboom niet hinderlijk is, maar integendeel staan dezelve onder deeze boomen zelfs zeer voordeelig en geven overvloed van vrucht".

Deze mededeeling wordt gedaan naar aanleiding van het bericht, dat de Spanjaarden de cacao ,te midden van hooge bosschen" planten.

1) Bij Guizan komt een rapport voor over de cacaocultuur in Venezuela, uitgebracht door iemand die in 1824 door den gouverneur van Cayenne daarheen gezonden was. Deze rapporteur beschrijft de cultuur onder Erythrina's en merkt op, dat men dien boom op de fransche Antillen niet zou kunnen gebruiken vanwege de orkanen, maar in Cayenne zou het best gaan.

Van Raders en Wolfson (Verslag eener reis naar Demerary, Grenada en Guadeloupe, Paramaribo 1846) berichten, dat op Grenada de cacao geheel anders geteelt wordt als in Suriname.

$\mathrm{Ze}$ citeeren dan Edwards, History Br. Colonies in the West Indies, 4 ed. 1807, o.a. „Het wordt ook raadzaam geacht om den eenen of anderen boom (de erythrina of beantree neemt men gewoonlijk hier voor) ten Zuid Westen van de cacaoplant te planten, welke tegelijk met dezelve opgroeit en haar beschermt." Ook deelen zij mee, dat de koffie op Grenada onder een beschermenden boom geplant wordt. Deze heeren (zeeofficieren) schenen dus een tusschenplanting van schaduwboomen in koffie- en cacaovelden in Suriname niet te kennen.

$\left.{ }^{2}\right)$ Onder dezen naam staat tegenwoordig een Acanthacee, Trichanthera gigantea H. B. K. bekend, die nog wel eens als windbreker gebruikt wordt, daar ze zeer gemakkelijk en snel groeit. 


\section{GESCHIEDENIS DER CACAOCULTUUR IN SURINAME}

Blom teekent over het aanleggen van cacaovelden nog aan: „Men kan ook wel eenige wilde boomen, mits die hoog van stam zijn, op zekeren afstand laten staan om schaduw aan de Cacao te geven; terwijl die onder de schaduw, die echter niet bekrompen, maar ruim moet zijn, zeer wel tiert. Echter is dit geen noodzakelijkheid, want in de open lucht, in goede zwaare gronden geplant zijnde, groeit ze zeer wel., en zoo groot dat de een de ander tot schaduw kan strekken."

De mededeeling uit de jaren 1740-1747, dat men de bananen kan laten staan tot de cacao zijn kroon gevormd heeft, en ,zoo veel kragte ontvangen heeft dat hij sig van andere Hulpe niet van noode heeft te bedienen", wijst er ook duidelijk op dat geen blijvende schaduwboomen geplant werden.

Uit het bovenstaande blijkt voldoende dat tusschenplanting van Erythrina's in cacao- en koffievelden in de 18de eeuw in Suriname niet in gebruik was. Erythrina glauca komt voor zoover mij bekend is, in Suriname niet in hêt wild voor; in de zwampen achter de plantages in Nickerie is ze waarschijnlijk verwilderd ${ }^{1}$ ) en afkomstig van die plantages zelf. Toch schijnt men vroeger (voor andere doeleinden) wel Erythrina aangeplant te hebben.

M. S. Merian (1726) geeft een duidelijke afbeelding van een Erythrina ,waarschijnlijk glauca, op plaat 11 van haar verhandeling over Surinaamsche insecten. Ze beeldt daarbij dezelfde rups (ook de vlinder) af, die nog heden ten dage koffiemama-rups genoemd wordt (Arsenura erythrinae Fabr.) en vaak de koffiemama's kaal vreet, wanneer ze na hun bloei in den grooten drogen tijd, weer in blad gekomen zijn.

De aan de plaat toegevoegde beschrijving van de „pallisade" berust blijkbaar op een vergissing en slaat op den pallisade-palm (Euterpe oleracea), niet op Erythrina. Waarvoor deze boom gebruikt werd in de 18de eeuw is mij

1) J. W. Gonggrijp (houtvester in Suriname) meent dat deze boomen wild zijn. Hij zag ze op dezelfde wijze groeien langs de beneden-Orinoco. Ook trof hij den boom aan op Baviaan-eiland in de Corantijn. 
niet bekend, mogelijk als laanboom, zooals Hura crepitans (vergel. Hartsinck, dl. I, p. 73). Van E. inermis Aublet werd in Cayenne een dergelijk gebruik gemaakt (NoyerForets vierges, 1827).

Aublet, die 1762 in Fr. Guiana kwam, beschrijft 2 Erythrina's. Eén vond hij in de vlakte van l'île de France; de wortels en bloemen daarvan golden als geneeskrachtig, over een ander gebruik wordt niets gezegd. (Hist. des Plantes de la Guiane Française. Tom. II, 1775, p. 760). Reeds eerder wordt een „immortel” beschreven door P. Barrère, die 1722-1725 in Fr. Guiana was, in zijn „Essai sur l'histoire naturelle de la France équinoxiale".

Voor Suriname wordt Erythrina crista galli. (Mangonie?) genoemd in J. Alm, Plantae Surinamenses, Upsala 1775.

Andere berichten over het voorkomen van Erythrina in de Guiana's heb ik in de mij ter beschikking staande 18de eeuwsche litteratuur niet gevonden.

Door G. F. W. Meyer (Primitiae Florae Essequeboensis 1818) wordt Erythrina glauca Willd. beschreven als een wilde boom en niet onder de gekweekte genoemd. Richard Schomburgk (Reisen in Br. Guiana 1848, dl. III, p. 856) noemt Erythrina Corallodendron L. als geïmporteerden boom, die evenals Erythrina speciosa Andr. vanwege de fraaie bloemen in tuinen gekweekt wordt, echter E. glauca Willd als wilden boom uit het savanna-gebied, dl. III, p. 1203).

Robert Schomburgk noemt bij zijn beschrijving van de Berbice een grooten "Orenocoboom" (Erythrina spec. ?).

Van het begin der cultuur af is men er in Suriname van doordrongen geweest dat de cacao tegen den wind moet beschermd worden.

De onder 2 aangehaalde memorie van 1735 geeft aan, dat de aanplanting omgeven moet worden door een dubbele rij bananen of "waterwilligen" tot bescherming tegen den wind.

Het handschrift uit de jaren 1740 - 1747, teekent aan, „De kakaauw vereyscht wel ter eerster Instantie, dat hij 


\section{GESCHIEDENIS DER CACAOCULTUUR IN SURINAME}

niet zooveel voor de son, als wel principaalyck voor de wint bewaart wordt"' 1 ).

Nepveu (1770) geeft aan, dat de cacao, vooral als ze jong is, niet tegen wind kan. Daarom is een aan den windkant door bosch of boomen beschutte plaats het beste.

Blom (1787) klaagt ook over de windschade, ,,zelfs wanneer een boom in het midden van een stuk komt te sterven, moet men aanstonds, al is het van gemeen hout, zorgen, dat de ledige plaats vervuld wordt, anders sterven de naast gelegen boomen mede weg, en men loopt gevaar van een gantsch stuk te verliezen". Het is dan ook zeer aannemelijk, dat men in dergelijke cacaovelden zonder tusschenplanting met schaduwboomen voor windschade zeer op zijn hoede moest zijn.

Guizan (1788) beveelt het planten van windbrekers aan de N. en O. zijde der cacaostukken aan; eerst neemt men bananen en later plant men vruchtboomen daartusschen; goed is het ook eenige van die windbrekende heggen rondom de stukken te brengen.

Ludwig (1789) zegt, dat men bij een cacaoplantage altijd veel nieuwe boomen moet naplanten, omdat er vaak door den wind bedorven worden.

In een latere publicatie (1805) raadt Blom aan om als windbrekers aan de $\mathrm{N}$. en $\mathrm{O}$. zij van de cacaostukken bamboe te planten.

Ten slotte mag er nog op gewezen worden, dat de cacaoboom welke zonder schaduw gekweekt wordt, een andere habitus heeft dan de beschaduwde. De vorm is meer gedrongen. In de plantage Margarethenburg, waar indertijd verschillende cacaovelden zonder schaduw aangelegd wa-

1) Ook Labat (1728) en de Quélus (1720), die een nauwkeurige beschrijving van de cacaocultuur op de Fransche Antillen leverden, spreken van windbrekers nl. 3 rijen bananen; Labat noemt ook een heg van ,immortellen" (Erythrina) als zoodanig.

M. Buc'Hoz (1787) die zijn inlichtingen over de cultuur vooral dankt aan een artikel van Artur (Cayenne) zegt: „On dit que l'ardeur du soleil pouvait nuire aux cacaoyers, surtout dans les terres argileuses, et dans celle ou le sable domine. „Le vent est bien plus dangereux pour les cacaoyers que le soleil". Een laag windbrekers rondom het terrein meestal bestaande uit bananen of bacoven is noodzakelijk. 
ren ${ }^{1}$ ), maar omstreeks 1915 alle stukken weer beplant zijn met koffiemama, herkent men de vroeger schaduwlooze stukken nog duidelijk aan de gedrongen lage vertakte boomen.

Dat de zonder schaduw opgegroeide cacao een geheel andere habitus had dan de tegenwoordige onder schaduw gekweekte, blijkt o.a. uit de volgende beschrijving van Blom (1786):

Boom tot 10 voet hoog ${ }^{2}$ ). Naarmate de boom groeit, buigen de takken zich meer en meer naar den grond, zoodat de onderste den grond raken; ten slotte sluiten de takken aan elkaar en bedekken den grond geheel, (plantwijdte 16 - 18 voet). De stam is 2 voet hoog. Wanner het lang droog was, vielen de bladeren soms af, maar met den regen liepen de boomen opnieuw uit.

Guizan (1788) zegt van den cacaoboom: ,il a toujours une grande partie de ses branches dont les sommités sont mortes. Il offre assez souvent l'apparence d'un arbre qui a été grêlé ou battu de l'orage ${ }^{3}$ ).

Zooiets vertoonen gezonde beschaduwde boomen niet, maar wordt in het droge seizoen niet zelden waargenomen bij boomen, die in de volle zon staan.

\section{Snoeien, wieden en ander onderhoud.}

Over deze onderwerpen zijn weinig gegevens te vinden. Hoewel de meeste auteurs er op wijzen, dat het zeer moeilijk is om de jonge cacao op te kweeken, geven allen toe, dat wanneer eenmaal de cacao volwassen is, ze zeer weinig arbeid meer eischt. Men krijgt den indruk, dat aan de volwassen cacao zeer weinig gedaan werd.

Merian (1727) merkt op, dat de cacao-doppen dienen als mest.

Ook de reeds meer genoemde planter, uit de jaren 1740

1) Zie van Hall (1907).

$\left.{ }^{2}\right)$ Hartsinck (1770) $11-12$ voet.

3) de Quélus (1720) schrijft dat op de Fransche eilanden, de cacao (ook zonder schaduw geteeld) vaak veel dood hout, vooral aan de uiteinden der takken, heeft. 


\section{GESCHIEDENIS DER CACAOCULTUUR IN SURINAME}

-1747,, zegt, dat de schillen der cacao gebruikt worden om ze rondom de zieke en magere boomen te leggen. Verder: „De kakauw heeft van de Natuur de begaaftheydt, dat hij gelijk men segt, geslooten sijnde, geen wiet of gras omtrent hem laat groeyen, en dat hij sig met zijn eygene afgevalle blaaden voeyt en mest". Aan onderhoud ${ }^{1}$ ) werd dus blijkbaar niet veel gedaan (1 slaaf verzorgde 2000 boomen). Wel wordt gezegd, dat cacao evenals koffie licht overwoekerd en verstikt wordt door patatten-ranken ${ }^{2}$ ). Het is dus zeer aannemelijk, dat die tijdig verwijderd werden. De zonder schaduwboomen geteelde koffie en cacao zal er zeker meer door hebben te lijden gehad dan beschaduwde.

Nepveu (1770) zegt: ,Men moet in de cacoboom so wynig mogelijk kappen, alleen het drooge hout en de takken, die vermolmen wegnemen, ook de waterlooten".

De cacao is volgens hem gemakkelijker te onderhouden dan de koffie en geeft als ze eens groot is, minder wiedwerk, omdat er geen onkruid onder groeit.

Blom (1787) geeft op, dat onderaan eenige takken weggesnoeid werden om in de stukken te kunnen komen bij het oogsten; merkt echter in een later geschrift (1801) op dat det afsnijden van takken bij de cacao heel slecht is, de groei en productie benadeelt en bederf en kanker veroorzaakt.

De cacao geeft weinig wiedwerk. Men moet gedurig de bladen uit de ,,trenzen" halen, anders wordt de „loozing” belemmerd. Het schoon maken van de groote en de kleine trenzen moet in het regenseizoen om de 3, uiterlijk 4 weken geschieden, alle onkruid (als sarre sarre, pannekoeken, watergras e.d.), die de loozing belemmeren, moeten er uit gehaald worden. „De goede afwatering is zeer nuttig voor alle gewassen; men kan nooit te oplettend met het

1) Bij Labat (1725) en de Quélus (1720) wordt meegedeeld, dat men op de Fransche Antillen het doode hout meest liet zitten: De Spanjaarden („hoewel zeer lui en traag”) lieten nooit na het tijdig weg te snoeien. Gewied werd tot de jonge cacao den grond bedekte en het onkruid onderdrukte, daarna achtte men 1 maal per maand wieden voldoende.

$\left.{ }^{2}\right)$ Ipomoea sp., is nog steeds een zeer lastig onkruid. 
schoon maken van trensen, en eene behoorlijke bedelving zijn".

Ludwig (1789) merkt op, dat het z. i. evenveel werk geeft om een cacaoplantage te snoeien en schoon te houden als een koffieplantage.

In de Verhandelingen der plantersvereeniging: „De Eensgezindheid" (1804) wordt aangeraden cacao slechts licht te snoeien, het dorre hout en de waterloten weg te nemen; de cacao moet heel anders gesnoeid worden als de koffie en katoen. Ook moet men de „vogelkaka” verwijderen en de worm onder de bast.

Guizan (1788) houdt het mos voor schadelijk; het houdt het regenwater vast en bederft bloemen en vruchten. Men reinigt de boomen daarom als ze weinig bloemen hebben.

Teenstra schrijft (1835): „De kakau boom moet ligt gesnoeid worden, vooral daar hij zijne vrucht niet in het jonge- maar oude vaste hout draagt.... men neme dus alleen de zuigers (waterloten), het hinderlijke en vooral het doode hout weg.

Anderen snoeyen de stam tot 4 voet hoogte op, en laten de kruin op 3 takken groeyen" (de overtollige takken worden op 2 vinger breedte van den stam afgesneden).

Onder het onkruid zijn het $\mathrm{zg}$. klimop ${ }^{1}$ ) en de paruiken, die op de takken uit het „,vogelkaka” ${ }^{2}$ ) groeyen, het ergste, welke men beide bij de snoeying wegnemen laat; ook is het zeer nuttig, stam en takken, bij regenachtig weer, door middel van een houten mes, van het daar aan groeijende mos te laten zuiveren.'

Aan grondbewerking en bemesting voor oude cacao werd blijkbaar niet gedaan (wel voor de jonge planten; zie onder 2).

Wat de ,,bedelving" betreft, het volgende:

De planter van (1740) beschrijft de kleine trenzen als 3 voet breed en 2 voet diep. De bedden zijn voor koffie (waarschijnlijk ook cacao) $30-33$ voet breed.

Nepveu (1770) deelt mee, dat de meeste cacao- en koffie plantages 30 ketting breed zijn en door paden in 3 vakken

1) Blijkbaar wordt de genoemde Ipomoea bedoelt.

$\left.{ }^{2}\right)=$ Phthirusa e.a. Loranthaceēen. 
verdeeld zijn. Meestal is er om de 10 ketting een dwarspad waarlangs een trekker. De bedden zijn voor koffie (waarschijnlijk ook cacao) 33 voet breed, de kleine trenzen 3 voet breed en 3 schop diep.

Volgens Blom (1787 is de verdeeling in bedden bij cacao dezelfde als bij koffie, de kleine trenzen zijn 2 voet 3 duim breed, 2 schop diep ( 1 schop $=9$ duim). De oude trenzen moeten om de 3-4 jaren worden uitgediept ; 20 duim is een voldoende diepte. De trekkers zijn $4-5$ voet breed, 3-4 schop diep.

Als afmeting der kleine trenzen geldt tegenwoordig meestal $2 \frac{1}{2}$ voet breed, bij 2 voet diep voor de trekkers 5 voet breed bij $2 \frac{1}{2}-3$ voet diep (d. i. iets dieper dan de kl. trenzen, de breedte der bedden is gewoonlijk 30 voet; een en ander is, al naar gelang van plaatselijke omstandigheden, aan geringe wijzigingen onderhevig.

\section{Productiviteit}

Daar cacao zonder blijvende schaduw over het algemeen eerder in volle vruchtdracht komt, meer produceert, maar van korter duur is dan beschaduwde boomen, zijn de gegevens over dit onderwep van belang.

In aanmerking moet echter genomen worden, dat men in het begin der 18de eeuw voornl. Criollo plantte, welke minder draagt en later in productie komt dan de tegenwoordige Amelonadotypen.

De planter van 1740 rekent de gem. productie per boom op 3 pond. Daar hij 185 boomen per akker rekent, was dus de gem. productie per akker volgens hem ongeveer 555 pond.

Volgens Nepveu (1770) geven de boomen dikwijls tot 5 pond per jaar door elkaar gerekend en enkele boomen tot 12 en 15 pond (plantwijdte 12 vt.). De ordinaire cacao (waarschijnlijk de oude Criollo zie II) draagt gewoonlijk maar 12-18 jaar, de Caracas (waarschijnlijk een Forastero), wel eens zoo lang,, draagt echter minder vruchten. De bovengenoemde planter merkt dat ook op en stelt 30 goede vruchten aan een "Carakische" tegen 50 aan een 
„Surinaamschen”, echter zijn de vruchten van de eerste grooter, zoodat de productie vrijwel gelijk staat.

Blom (1787) rekent dat de boom in het 4de jaar ${ }^{\mathbf{1}}$ ) in productie komt, in het 8ste jaar in volle dracht is en dan 3 pond levert. Op vele suiker-en koffieplantages werden eenige boomen voor eigen gebruik geplant; „sommige van deze boomen zijn wel 50 à 60 jaaren oud, staan zeer fleurig en geeven nog hunne volle revenue".

In de begrootingen wordt ook 3 pond per boom aangenomen ( 250 boomen per akker).

In een latere publicatie (1801) rekent hij ook 3 pond per boom per jaar (plantwijdte 16-18 vt.) In vruchtbaren grond wordt de boom tot 60 jaar oud, maar na 40 jaar begint hij achteruit te gaan.

Volgens Guizan (1788) heeft men in Suriname gedurende jaren de productie opgenomen en rekent men als de boom in volle dracht is (9-10 jaar) $4-8$ pond cacao per jaar. Wanneer men boomen van verschillenden leeftijd naast elkaar heeft, wordt 3 pond per boom aangenomen.

In Suriname plant men slechts 275 boomen per akker en haalt niet meer dan 825 pond per akker. Guizan meent, dat er wel 450 boomen op een akker kunnen staan en dat dan ook op 3 pond per boom kan gerekend worden ${ }^{2}$ ). In goed laag land duurt de cacao volgens hem tot 40 jaar en gaat dan achteruit. Echter kan men de boomen dan op 6 duim boven den grond kappen en de 2 beste loten aanhouden (dat kappen geschiedt bij voorkeur in Nov. of anders in Febr.). De aldus verjongde cacao kan dan nog weer 15 -20 jaar mee; hoe lang is nog niet juist bekend.

Volgens Ludwig (1789) beginnen de boomen te bloeien als ze $2 \frac{1}{2}$ jaar oud zijn en zijn ze na 6 jaar op volle kracht. De opbrengst kan niet worden opgegeven, daar die van vele toevalligheden afhangt. Er zijn boomen die 200-300 vruchten dragen. Dit geeft elke vrucht op 20-25 pitten

\footnotetext{
1) Vgl. noot 1, p. 61.

$\left.{ }^{2}\right)$ Volgens hem heeft men vele jaren lang proeven genomen met dicht en wijder planten en vond men geen verschil, zoodat men hel er nog niet over eens is of op 10-12 of 8-9 voet moet geplant worden.
} 
gerekend en ongeveer 300 droge pitten in een pond, 24 pond cacao.

De Verhandelingen van 1804 stellen, dat de cacao eerst in het 6de en 7de jaar productief is.

Als gemiddelde productie van goed onderhouden cacao (onder schaduw) wordt tegenwoordig in Suriname aangenomen 200 K.G., hoogstens 250 K.G., per akker van 180 boomen, dus 1.1-1.4 K.G. per boom. De duur van een aanplanting wordt gesteld op 50 jaar. Men rekent dat ongeveer in het 4de jaar de eerste vruchten geoogst worden en dat de boom in het 8ste jaar in volle dracht is.

Gaan we nu na, of de schaduwlooze cacao eer in productie kwam, meer produceerde en korter duurde dan de onder schaduw gekweekte, dan komt slechts de meerdere productie uit.

Blom en Guizan komen tot resp. 750 en 825 pond per akker, wat bijna het dubbele is van de tegenwoordige productie. Allen nemen minstens 3 pond per boom aan.

Het is aanemelijk, dat de schaduwlooze cacao wel op 12 voet afstand had geplant kunnen worden, zooals Nepveu en Guizan aangeven. De duur der productiviteit kan blijkens de opgaven van Nepveu en Blom op 30-40 jaar gesteld worden ${ }^{1}$ ), bij de oude Surinaamsche Criollo was het de helft minder (Nepveu). De opgaven van Blom betreffende het in productie komen, in volle dracht zijn der cacao komen met de tegenwoordige gegevens overeen.

\section{Oogt en bereiding}

Merian (1727) deelt over de bereiding slechts mee, dat men de zaden of boonen in de schaduw laat drogen, voor ze uit het land gezonden worden.

Volgens den planter uit de jaren 1740-1747 worden de rijpe vruchten geplukt of met een speciaal daarvoor gemaakt ijzer afgestooten, in manden gedaan, opengesneden en naar huis gebracht, daar in bakken gelegd en in koude

1) Ze hebben blijkbaar de vruchtbare alluviale gronden der benedenrivieren op het oog. 
asch gewenteld en vervolgens door de zon gedroogd. Bij regen werden ze toegedekt.

Een speciale fermentatie werd dus waarschijnlijk nog niet toegepast, wat voor de Criollo dan ook veel minder noodig is als voor de Forastero-cacao. Wellicht werd de cacao des avonds op een hoop gehaald en toegedekt, zoodat daardoor toch licht gefermenteerd werd ${ }^{\mathbf{1}}$ ).

Nepveu (1770) schrijft ,als de vrugt rijp is, hetgeen men aan zijn geele koleur siet, wort se afgehaalt met een krom snoeymes, de koker doorgesneede, en de pitten in een mand gedaan en dus na de loos gedragen, daar men ze op een hoop needer gooit en met bannanneblaaden of anders toedeckt en 24 uuren laat sweeten, om de rinssoete slijm die er om sit los te maaken, en dan word se met asche of sand bestrooit en geroert en vervolgens gedroogt. Als de cacao tusschen de vingers gedrukt wel breekt en open gaat dan is ze goed om te inbaleeren, ter versending hetzij in vaaten of in baalen".

In een later (blijkbaar verbeterd) afschrift zijner „Annotatiën" wordt de cacao 2 maal 24 uur gefermenteerd, daarna wordt ze, ,met assche of gedroogde, gestoote en gezifte kley-aarde bestrooyt en geroert, vervolgens gedroogt dog niet in sterke Sonneschijn, maar meest in de Wind".

Uitvoerig wordt de bereiding door Blom (1787) besproken. De vruchten worden in het veld opengekapt, (sommigen laten ze eerst een dag liggen) en de pitten naar huis gebracht. Daar legt men ze op hoopen van \pm 300 pond, dekt ze met bananen-bladeren toe en legt er planken op, zoodat de bladeren niet wegwaaien. Men laat ze zoo $6-7$ dagen broeien, maar roert ze elken morgen om. Het slijm verdwijnt. Na het fermenteeren neemt men fijn gezeefde

1) Dat is than" nog in Venezuela en Ecuador in gebruik.

D.Quélus (1720) en Labat (1725) (de laatste wordt door onzen planter geciteerd) geven op, dat op de Fransche Antillen 4-5 dagen gefermenteerd werd. Volgens Labat kwam de cacao in groote houten bakken, die met bladeren en matten werden toegedekt en geperst met planken en steenen.De gistende cacaoboonen werden elken morgen gekeerd.

Volgens D. Quélus werd de cacao op een hoop geworpen met paloeloebladeren toegedekt en dagelijks gekeerd. Na 4 dagen was ze gereed, wat herkend werd aan de kleur („,beaucoup plus foncée et tout à fait rousse”). 
asch, of gewasschen klei, die gedroogd, gestampt en gezeefd wordt en wentelt de cacao daarin terwijl ze nog nat is, spreidt ze vervolgens op den zolder van de loods dun uit keert ze dagelijks om, om ze gelijkmatig te doen drogen. $\mathrm{Na} 4-5$ weken is de cacao gereed om afgeleverd te worden; men verzendt ze in balen van 140 pond of in vaten van 300 pond. Ze wordt tusschendeks geladen in schepen met suiker, waardoor de smaak verbetert.

Volgens Blom bederft de cacao als men ze in den zon droogt; ook Nepveu schijnt de sterke zonneschijn voor schadelijk te houden. Welke reden men daarvoor had is mij niet duidelijk. Opmerkelijk is dat bij Blom zooveel langer gefermenteerd wordt als bij Nepveu.

Wanneer men aanneemt dat de herleefde cacaocultuur na 1760 vooral met forastero gedreven werd, is zeker een fermentatie van ongeveer 1 week noodig geweest.

Guizan (1788) geeft de volgende beschrijving:

Geoogst wordt met een gesteeld snoeimes op een langen stok. De vruchten worden in het veld opengekapt. In Suriname laat men de cacao fermenteeren op hoopen. In plaats van ze te keeren verplaatst men ze elken dag. Beter is in houten bakken te fermenteeren (steenen bakken zijn minder goed) zooals de Spanjaarden doen. Het eenige nut van het fermenteeren is, dat men de zurigheid wegneemt en dat men water onttrekt. Als men te lang fermenteert wordt de cacao slecht, men moet ze daarom alle dagen ('s morgens en s'avonds) keeren. Fermenteeren en drogen nemen ongeveer 15-18 dagen in beslag.

Als de cacao gereed is, moet men ze zoo spoedig mogelijk verschepen, omdat ze anders door de insecten bedorven wordt. Men beweert, dat men die insectenschade deels kan voorkomen door er tijdens het fermenteeren asch of kalkmelk door te mengen, zooals van ouds in de Hollandsche kolonies is toegepast.

Cacao, die niet lang genoeg gefermenteerd heeft („,cuve rouge") ziet er mooier uit en weegt zwaarder dan de goed gefermenteerde („cuve brun”), maar de chocolade is scherp; de handel prefereert ze echter.

Ook Ludwig (1789) spreekt van het op hoopen fermen- 
teeren onder bananenbladeren in de koffieloods. Na eenige dagen werden de pitten met asch gewreven om ze van het slijm te ontdoen en onder vlijtig keeren aan de lucht of zon gedroogd.

Volgens de Verhandelingen der plantersvereeniging „De Eensgezindheid” (1804) kan men op 2 manieren fermenteeren:

1) op hoopen, met persenningen of bananenbladeren bedekt.

2) in kisten of bakken.

De eerste methode is de beste omdat men de pitten beter kan keeren en ze beter doen uitwasemen. Ze worden dagelijks gekeerd, liefst 2 maal per dag; hoe losser de cacao ligt hoe beter. Het fermenteeren gebeurde op de drogerij of als op de loods geen plaats meer was in de open lucht. Zoodra de pitten op breuk een ,egale paarsche of violetkleur" vertoonden (meestal na 8-12 dagen) werd de fermentatie voldoende geacht. Daarna werd de cacao uitgespreid en strooide men er asch of gedroogde fijne kleiaarde op en keerde de cacao terdege met de handen, opdat de asch of fijne aarde goed aan de nog kleverige pitten hechtte. Dan werd het product in de zon gelegd om te drogen en nu en dan met de handen gekeerd, tot de asch of klei er vast aan zat en de cacao droog was.

Daarna kwam ze in de loods om verder te drogen en werd later nog eenige dagen in den zon gelegd opdat ze geheel droog zou zijn. De slechte boonen werden uitgezocht, de rest in vaten of zakken gepakt. Asch werd voor beter gehouden dan klei, omdat de cacao sneller droogde en beter bestand was tegen de „mijt” ${ }^{1}$ ), waardoor het product veel leed.

Teenstra (1835), laat de vruchten ook in het veld openen (in de lengte opensnijden). In de koffieloods (de meeste cacao in Suriname werd op de koffieplantages verbouwd) werd de cacao op een hoop geworpen en begoten met water daarna met bananenbladeren of geteerd zeildoek bedekt. Een maal per dag werd gekeerd. Bij regen

1) Waarschijnlijk wordt de cacaomot (Ephestia sp.) bedoeld. 


\section{GESCHIEDENIS DER CACAOCULTUUR IN SURINAME}

weer moet de cacao wel 5-6 dagen langer ,zweeten” dan in den drogen tijd. De boonen nemen een donkerroode en violette kleur aan.

Vervolgens worden ze op matten of schuifbakken in de zon gedroogd en met asch of fijn gezeefde klei bestrooid, waardoor ze spoedig drogen en voor de mijt gevrijwaard worden. Bij goed weer gebeurt dit in 3 dagen. Als de cacao niet goed gedroogd is, gaat ze broeien en bederft ze; als ze te sterk gedroogd is, vergruist ze. Voor regenachtig weer zou Teenstra het goed achten de cacao door middel van over de zolder gelegde kachelpijpen te drogen ${ }^{1}$ ) en droog te houden. De cacao werd verpakt in koffiezakken, die 200 pond koffie en ongeveer 170 pond cacao konden bevatten. Ook werd de cacao wel eens in vaten verpakt, die 4 zakken bevatten (600-700 pond).

1) Droogoven- schenen in Cayenne wel in gebruik te zijn. (Zie Guizan, p. 396-402). Gemetselde haarden om koffie te drogen werden in Suriname reeds in 1740 gebruikt (zie Handschrift 1740), maar in Holland keurde men dat af.

(Slot volgt.) 